\title{
INFORMATION LITERACY \\ AS A HUMAN RIGHT
}

\author{
Paul Sturges \\ Professor Extraordinary University of Pretoria, South Africa and \\ Professor Emeritus, Department of Information Science, \\ Loughborough University UK. \\ Email: R.P.Sturges@lboro.ac.uk \\ and \\ Almuth Gastinger \\ Senior Research Librarian \\ Norwegian University of Science and Technology \\ Trondheim, Norway. \\ Email: almuth.gastinger@ub.ntnu.no
}

\begin{abstract}
A clear line of argument can be set out to link the (passive) intellectual freedom rights offered by Article Nineteen of the United Nations' Universal Declaration on Human Rights, to a consequent responsibility on governments, professionals and civil society activists for the (active) creation of suitable conditions for the effective exercise of intellectual freedom. Commentators on media in society and socially responsible computing are also increasingly drawing conclusions of this kind and stressing the importance of Media Literacy and Computer Literacy. This line of argument naturally directs attention towards the rationale currently offered for Information Literacy as a focus of professional activity. Whilst there are many elaborately worked-out programmes for Information Literacy instruction, these have so far been largely derived from practical perceptions of need. However, broad statements such as the Prague Declaration 'Towards an Information Literate Society' of 2003 and the Alexandria Proclamation of 2005 can be seen as beginning to point towards a rationale for Information Literacy activities rooted in human rights, Article Nineteen in particular. The contention is that starting from a human rights perspective leads towards a strong, inclusive interpretation of Information Literacy. This subsumes Media Literacy, Computer Literacy, Web Literacy and, to a considerable extent, Civic Literacy into a model that serves human needs rather than the established priorities of information professionals. The value of this approach for both practice and research is stressed.
\end{abstract}

\section{INTRODUCTION}

In this paper we set out to explore the ability of the idea of access to information as a human right to generate what we believe are persuasive arguments in favour of the practice of Information Literacy instruction. We will start with some explanation of this notion of an information right before moving on to develop a line of reasoning that we believe is not merely academically interesting, but offers useful potential for those developing Information Literacy programmes.

The starting point is Article Nineteen of the United Nations' Universal Declaration of Human Rights, which states that everyone has a right to freedom of expression. The important thing is that this Article then goes on to make it clear this effectively 
includes a right of access to information. This is expressed as the right to "seek, receive and impart information and ideas, through any media and regardless of frontiers" (The Universal Declaration of Human Rights 1948). A more significant statement justifying the work of the information professions is hard to imagine, though it is not cited as frequently in professional debates and writings as it deserves. However, IFLA (the International Federation of Library Associations and Institutions) encourages the profession to look to Article Nineteen for inspiration, and chiefly does so through the work of its Freedom of Access to Information and Freedom of Expression (FAIFE) core activity (of which the first author of this paper was Chair 2003-2009).

IFLA FAIFE has drawn a firm, but not fully specific conclusion that Article Nineteen points towards an emphasis on access in the policy of libraries. Whilst FAIFE might originally have been seen as confining its work to defending intellectual freedom in libraries when threats arose, it has expanded this mission very considerably. In the interests of the emphasis on promoting access FAIFE has, during the period 2007 to 2009, put on Workshops in developing countries designed to encourage active promotion of Internet use, and the provision of HIV/AIDS information for the general public. During 2009 the concept of empowerment through access to health information has been broadened by developing workshop materials on Public Access to Health Information. These were piloted in East Africa in August of that year. A further programme following from FAIFE's IFLA Manifesto on Transparency, Good Governance and Freedom from Corruption (IFLA 2008) has also been developed during 2009. The success of these programmes has encouraged a reflection on the development of a more specific rationale to connect Article Nineteen with accessrelated policies. It has also suggested the value of openness to wider implications that can be drawn from this line of thinking. Exploring ideas on Information Literacy has been a natural consequence of this reflection.

The problem is that while Article Nineteen provides excellent inspiration, like any simple statement of a human right, it does not offer supporting arguments that might indicate the specific dimensions and potential structures of an information right. These have to be reasoned out separately. For instance, one common conclusion is that nations need laws for freedom of information or access to information that allow the public to obtain access to official documentation by right. Over 70 states have passed such laws, varying greatly in their effectiveness, but all reflecting the idea that the information right stated in Article Nineteen requires this type of legislation to make it real. When we say that Article Nineteen has relevance for the information professions, we are thus following a similar process of reasoning, although we are looking at existing institutions and services (library and information systems) and offering retrospective justification for their work. This is valuable because it can be contended that library and information work lacks rigorous arguments for its rationale. The developing field of Information Literacy work shares this problem, as we will seek to demonstrate. Having looked at existing arguments for Information Literacy, we will go on to develop a line of argument from Article Nineteen, and offer some suggestions as to why this offers real benefits for the practice of Information Literacy instruction. 


\section{DEFINITIONS}

There is an enormous growth in programmes in libraries that offer training and support for Information Literacy, but still a strong tendency for them to be driven by the priorities of librarians. The reader can assess the justice of this claim from several international surveys (Andretta 2007; Curzon \& Lampert 2007; Lau 2008) or by a trawl of the Web using obvious search terms. The programmes tend to be predominantly in academic institutions, and consist of lectures and practical work with a strongly didactic character. That is to say, there is an emphasis on teaching about the structures and facilities already created by librarians for their users, with a concentration on using the OPAC, how to search in databases, and how to find books in the library shelves. What is more, we can still find statements that show a line of connection between the User Education of the 1970s and 80s and present-day Information Literacy programmes.

Sometimes this is absolutely explicit, for example, "Information Literacy has been known by many different names: library orientation; bibliographic instruction; user education; information skills training" (UK Information Literacy Website). We would contend that none of these were more than possible minor components of Information Literacy as it is now defined. Anyone who had much connection with the practice of User Education will know that the overwhelming tendency was for it to consist of routine presentations of what the library does, what it can give access to, and how users can benefit from these existing structures. It not only bored the students who were the recipients, but it seldom set out to promote a vision that was bigger than creating 'good' library users. There was little emphasis on critical thinking, and no real sense that it taught skills that could lead to a lifelong ability to participate more effectively in society. The librarians who presented it often seemed to share student disillusionment, and tended to display little enthusiasm or inspiration. User Education could be called a failed project, and one that used up enormous resources of professional energy for many years. If Information Literacy is no more than User Education under a new name then the information professions have made no real progress in the instruction they offer to the public.

Fortunately the old content of User Education is not the whole content of most modern Information Literacy programmes: the emphasis has moved towards developing a critical response to information in all formats (Spencer \& MillsonMartula 2009). A quick way to characterise this would be as a campaign to convince people that a simple search via Google is not enough for any serious purposes. By taking just one example of a good, recent text (Bothma et al. 2006) we can illustrate this. This book has a well-designed layout with many screen-shots of Internet pages that place it firmly in a twenty-first century context. It begins with definitions and a rationale for Information Literacy that roots it firmly in the human need for information with which to make decisions and perform tasks. It links this to the idea of lifelong learning, and the competencies of a highly functioning member of society. Process models for information literacy programmes by Eisenberg et al. (2004) and Thomas (2004) are outlined, and then the book works through sources of information, searching methods, ethical use of information, evaluating sources and other relevant topics in exemplary fashion. Is this sufficiently distinct from User Education to justify describing it as Information Literacy? Yes, it is. All it lacks, in our view, is the line of 
argument taking it back to a stronger concept than that of the individual's practical functioning in an information society.

Definitions of Information Literacy can be found in profusion, and they tend to follow this practice-oriented example. Probably one of the most cited definitions is that of the American Library Association (ALA 1989), which says "To be information literate, a person must be able to recognize when information is needed and have the ability to locate, evaluate, and use effectively the needed information." This is a rather dated and a typically narrow 'librarianship' definition, differing very little from the ways in which User Education was defined, although it will continue to be quoted because of the authority of the organisation from which it comes. It gives little hint that Information Literacy is principally an individual, critical approach to information rather than a set of mechanical tools that should be learned so as to obtain some kind of ideal product (the 'right' information). One could multiply examples of this type of definition, to little extra effect.

Better is another much quoted definition that talks of Information Literacy as "A set of competencies that an informed citizen of an information society ought to possess to participate intelligently and actively." This is more generous and outward-looking. However, while it occurs on website after website, sometimes as an unattributed quotation, sometimes as if it were an original part of a new statement, if there is a reference available, this seems to lead to an article at the website of the association EDUCAUSE. Unfortunately the offered Web address doesn't seem to exist anymore. We leave the task to identify the original source to the reader with high level Information Literacy skills or anyone curious enough to pursue it. The definition takes into account that Information Literacy means more than the ability to recognise when information is needed and to locate, evaluate and use the needed information. The powerful 'Statement on Information Literacy for all Australians' (ALIA 2001) makes this more explicit. It states that Information Literacy is a basic condition for: learning for life; the creation of new knowledge; acquisition of skills; personal, vocational, corporate and organisational empowerment; social inclusion; participative citizenship; and innovation and enterprise.

What we see in definitions such as this, is the writers striving to work out a strong rationale for an instructional activity that common sense tells them is obviously worthwhile. They need this rationale for a number of reasons, some of which we will go on to discuss in a later section. The immediate need is to convince the people they teach that Information Literacy matters to them. The argument from common sense may well be sufficient for this purpose: people receiving Information Literacy instruction are unlikely to feel much need for justifications based on theory. However, we would contend that even in these circumstances it is worthwhile to make the argument even stronger by taking it back to an information right. We are not entirely alone in arguing this: the beginnings of an approach based on information rights can be found in statements on Information Literacy made in the early years of the new millennium. In the next section we will draw attention to these.

\section{EMERGENCE OF A HUMAN RIGHTS ARGUMENT}

Stirrings of a more fundamental attitude towards Information Literacy can be identified, as for instance when the Scottish Information Literacy Project (2004-2009) 
referred to "information literacy as a civil right." This tendency can also be seen strongly in some international statements. These have begun to affirm the idea that Information Literacy is not just a necessity, but a basic human right that promotes social inclusion in all nations. For example, there is the Prague Declaration 'Towards an Information Literate Society' which proposed basic Information Literacy principles. Among others, these principles say that Information Literacy "is a prerequisite for participating effectively in the Information Society and part of the basic human right of lifelong learning" (Prague Declaration 2003). The significant point is that a right of lifelong learning is identified, to which Information Literacy is attached. The Declaration goes on to say that Information Literacy"should be an integral part of Education for All, which can contribute critically to the achievement of the United Nations Millennium Developments Goals, and respect for the Universal Declaration of Human Rights."

Whilst the idea that Information Literacy can contribute towards the achievement of the Millennium Development Goals is a natural extension of the line of reasoning set out in the Australian Statement quoted above, the reference to Human Rights is new. The wording is ambiguous, but seems to suggest that the information literate will respect the rights of others, rather than that they have their literacy as of right, but nevertheless the linkage is significant. The World Summit on the Information Society (WSIS) made a similar linkage in various of its statements, among others in the Declaration of Principles and the Civil Society Declaration. Both declarations highlight the importance of Article Nineteen of the Universal Declaration of Human Rights. In particular, the Civil Society Declaration states that Article Nineteen "forms an essential condition for human rights-based information and communication societies" (WSIS 2003). Once again the wording of the document does not make the significance of the linkage particularly clear, but the idea that there is a connection between the two is there.

It is to the Alexandria Proclamation that we need to turn for a clearer statement of this idea. Since the Proclamation was issued to influence the debates and findings of the World Summit, we can regard the Summit itself as having missed some of the points. The Proclamation describes Information Literacy and Lifelong Learning as the "beacons of the Information Society, illuminating the courses to development, prosperity and freedom." It also states that Information Literacy, as the core of Lifelong Learning "empowers people to achieve their personal, social, occupational and educational goals" and that it is "a basic human right in a digital world" (Alexandria Proclamation 2005). The fact that neither the Australian statement mentioned above, which cites the Proclamation as its inspiration, nor the World Summit pick up this line of argument suggest that it was a little before its time. Until the Alexandra Proclamation, the statements discussed above do not link the information right to Information Literacy, except almost in passing and then only by assertion. In the next section we will set about providing the necessary links.

\section{THE HUMAN RIGHTS ARGUMENT}

We believe that a clear line of argument can be developed to link the (passive) intellectual freedom rights offered by Article Nineteen with a consequent 
responsibility on governments, professionals and civil society activists for the (active) creation of suitable conditions for the effective exercise of intellectual freedom. What is needed to make this more solid is evidence that governments somewhere in the world have also felt that this is a valid argument. There is certainly one such example. A particular strong interpretation of the implications of Article Nineteen can be found in the new Article 100 of the Norwegian Constitution, promulgated in 2005. This not only specifies a right of access to government documents, but requires state authorities to create conditions that facilitate open and enlightened public discourse. The nature of these 'conditions' are not fully worked out, but Norway sees them as a complex of infrastructural provisions to include not only schools, but "public cultural institutions such as universities, libraries, museums, broadcasting and the like as well as the entire gamut of private institutions regulated and supported by the public authorities, such as media, publishers, theatres, cinemas or other public meeting places" (Norway 2005). These infrastructural elements, protected and effectively administered, should provide conditions conducive to freedom of expression in the public sphere.

The phrase 'the public sphere' leads into a particularly fruitful source of ideas for the information professions, the works of Jürgen Habermas. The theory of a public sphere (Öffentlichkeit), in which individuals could exchange knowledge and ideas has generally been identified with his name (Habermas 1989). His argument begins with the identification of a 'representational' culture, dominant until the eighteenth century in which rulers imposed their will and their image on the consciousness of their subjects. In contrast, he sees the emergence in the eighteenth century of a public sphere of forums effectively outside the control of the state, chiefly in England and the new United States of America. In this sphere individuals had the scope to develop their own ideas and communicate them in open discussion and debate, supported by print communication in the form of newspapers, pamphlets and books. Certainly the British culture of thousands of clubs and societies, from the eminent Royal Society founded in 1662, through to the humble clubs of flower and vegetable gardeners in provincial towns, was remarkably rich and energetic (Clark 2001). In such a social and intellectual climate freedom of expression was the norm, and the political change that Britain experienced in the nineteenth century can be traced back to it directly. Perhaps the most distinctive feature of the Eighteenth Century public sphere in Britain was that it flourished in a climate of neglect. By this we mean the neglect of the state to suppress a phenomenon that threatened existing structures and beliefs.

Habermas's thesis is that the public sphere has subsequently decayed under the pressures of a variety of forces, in which the influence of mass media and information consumerism is crucial. Decisionmaking, which had been close to the participants in the public sphere has moved to remote areas of bureaucracy and comparatively unaccountable government. This creates the need for the renewal of the public sphere, so that active formation of public opinion can once again flourish. The Norwegian government, through the new Article 100, can be seen as formulating a kind of response to Habermas's proposal. However, it stops short of detail on how the infrastructure of the public sphere, however well the government of a progressive state might nurture it, can truly create the active intellectual life that is its raison d'être. Institutions such as libraries, to take only the most relevant example, cannot by their mere existence guarantee a population actively engaged with ideas and capable of critical examination of the messages that reach them from all kinds of media. 
Our conclusion is that there is a demonstrable need to ensure that people have the skills to make best use of the rights that Article Nineteen offers. Commentators on media in society and socially responsible computing are increasingly drawing conclusions of this kind and stressing the importance of programmes of Media Literacy and Computer Literacy. A very similar message has also been drawn by information professionals, including those who have organised, presented, and assessed the FAIFE Workshop programmes. The whole Workshop activity points extremely strongly towards a requirement for Information Literacy programmes. Such programmes address the danger that libraries may offer access to information for a public that is, in fact, not fully able to make good use of that access. Without good levels of Information Literacy, the kind of overwhelming levels of access to information that are available today can simply confuse and deceive. By turning back to Article Nineteen and looking closely at its implications, as we have done here, the case for Information Literacy activity is clear.

\section{POTENTIAL OF THE HUMAN RIGHTS APPROACH}

If the need for the individual to possess Information Literacy is the logical outcome of a human right to information, programmes to develop information literacy are realisation of that right. But this conclusion means that the information literacy that we come to by this route is not the exclusive property of a profession, such as librarians. And at this point we need to recognise that, at the least, there are distinct definitions and major clusters of programmes supporting, media literacy, computer literacy, digital literacy, web literacy, civic literacy and critical literacy. Other literacies may well have been identified and developed, but the list is long enough to illustrate both their commonalities, and their differences. If we start, as librarians have done, with User Education and morph it into Information Literacy, the relationship to any other version of Literacy is more or less an interesting add-on.

If instead we start with a concept of information access as a human right, that leads us into the broad area of literacies and the programmes that support them without treating them as if the genuine distinctions between them actually make them genuinely distinct areas. The conclusion we reach when approaching the area from this direction is that individuals need a broad and self-selected set of skills across the range of formats and media to support their human right to information. This relates to the way people seek and use information (their approach is holistic and not necessarily limited by media or institutions) and potentially offers them the types of assistance that they want, rather than what a specific group of professionals think they should want.

The essence of the argument is that if we start from a human rights perspective, this leads towards a strong, inclusive interpretation of Information Literacy. We would argue that the term Information Literacy subsumes all of the specific forms of literacy, which share the same driving principle, but which are promoted by different professional groupings. This may be contentious, but the term has a level of generality that enables it to roll all the kinds of literacies have been identified, described and taught. To make this point, we need to provide a brief overview of some of the very wide and interesting range of such aspects of what we contend is the broader category. Information Literacy, as provided by libraries covers the range of sources, 
from print to digital, that a good modern library offers, but the focus of the other literacies varies from the more specific to the (probably) broader.

First of all, we will mention Media Literacy: the interpretation of what we obtain from newspapers and other publications, radio, film, TV and Internet news. The UK's Office of Communications (Ofcom 2009) defines Media Literacy as "the ability to access, understand and create communications in a variety of contexts." Media Literacy is possibly the most fashionable aspect of all literacies. Understanding the roles of owners, editors, journalists, and being aware of the confusing way in which what they say seems 'right' is part of this, but there is also the interpretation of the advertising and promotional messages that are such a ubiquitous aspect of the media world. There are great volumes of writing, speculative and propagandist, on the influence of media on behaviour. Studies of pornography and its effects on sexual behaviour are one high profile sector of this. Generally speaking, Media Literacy is more of an academic study than a matter of instructional practice, but media studies programmes in colleges and universities do teach students to understand the way language and images can be manipulated to influence ideas, opinion and (possibly) behaviour.

Computer Literacy, Digital Literacy and Web Literacy are three overlapping, but reasonably distinct approaches to the electronic side of the information world. Computer Literacy largely concerns itself with training in the use of computer software (chiefly the basic forms such as word processing, databases and spread sheets), applications and peripheral devices such as printers and scanners. Instructional programmes to help, children, adult and old people obtain a basic expertise in making devices work for them represent probably the most widespread form of information literacy activity. The internal workings of computers and programs are seldom, and wisely so, the concern of such instruction. Digital Literacy generally goes a step further than Computer Literacy and concerns itself much more with locating, organising, understanding, evaluating and creating content with the aid of computer technology. Definitions of Digital Literacy place some emphasis on understanding the operation of computer hardware and also pay attention to digital devices such as cell phones, and the Internet. Web Literacy, as the term implies, is concerned with evaluation and interpretation of Internet content, and the use of facilities such as blogs, wikis and social networking

Less familiar may be the concept of Civic Literacy. This is absolutely basic for citizens of a democratic society and those who hope to initiate change and introduce stronger democracy. It is based on functional literacy itself, includes interpretation of media, and the unpacking of political and propaganda messages. As an example of the way the term is used is the suggestion that the problems of the 1,000,000 people in the Internally Displaced Persons (IDV) camps of northern Uganda need civic literacy programmes. This is because 'Illiteracy and poverty are huge barriers to communication. The inability to read and write causes severe handicap when trying to either pass messages up the chain or gain information from local government. Newsletters and posters are only good if you can read them'. (Buttedahl and Nkurunziza, 2005) We would add 'and if you can work out who is trying to tell you what and why'. 
Finally, there is Critical Literacy: an even broader term than Information Literacy itself. Rooted in the educational ideas of Shor (1980) it effectively identifies the critical spirit as central to the whole educational process, or in modern terminology the learning process. Shor, in his own teaching sought to encourage students to probe beneath the surface meaning of the information and ideas to which they were exposed, so as to draw out the causes, context and ideology of all topes of communication. As such this inspires all of the literacies described above. To say this might seem to suggest that we should take Critical Literacy to replace the term Information Literacy as the enfolding, broad term. There are two problems with this, the first of this is the association of Critical Literacy with teaching as opposed to learning and the second is the flavour of literary criticism that the term 'critical' carries with it. Maybe an ideal term would be Critical Information Literacy. All of these cascade naturally from Article 19 by the route that we have outlined above. All of them need to be considered first of all as elements of a broader category (Information Literacy, we would contend) and then significant specialised enrichments of this category.

\section{CONCLUSIONS}

In conclusion, it is necessary to offer an answer to the question: Is this a useful line of argument, or is it merely a way of theorising about Information Literacy (more or less for theorising's sake)? To this we would answer that a unifying approach such as this serves the public more effectively than the creation of different forms of instructional support for various literacies, as is already offered by different professional groups in different institutional contexts. The approach opens up opportunities for synergies and alliances for the promotion of Information Literacy and the better design of instructional programmes. By this we mean that, for instance, it should encourage librarians to look beyond the library use aspects on which they normally concentrate. But most important of all, coherent arguments going back to basic principles like human rights are powerful ways to convince funders and administrators of the value of programmes. These programmes can be shown to be much more than just minor, technical matters.

We would also argue that a strong concept of Information Literacy relates very effectively to other requirements that can be identified by looking at the significance of an information right. As just one example of this, we have already identified the way in which an information right needs to be supported by specific access, such as those provided in Freedom of Information laws. Such laws are not easy for the ordinary person to use to good effect, and working with them is much better addressed by an information literate individual. There is obviously scope for information professionals to offer instruction in how to make and follow up formal enquiries under freedom of information legislation. This leads us back to FAIFE's advocacy and education work. This is inspired by Article Nineteen and takes the form of Workshop programmes that also have implications for the professional activity of instructors in Information Literacy. The FAIFE workshops on Internet Access, Public Access to Health Information, and Transparency were mentioned at the beginning of this article. These Workshop programmes all alert librarians and other information professionals to areas in which they can empower the public through information. This is not, however, only a matter of professionals informing the public. There is a 
clear implication in the content of all the Workshop programmes that what the professionals should try to do is to help people by developing their capacity to understand and interpret information.

Finally, the argument developed in this article can be turned towards research and development activity. We have suggested that if we start with the idea of an information right it leads us on towards a need for Information Literacy programmes, defined in the broadest possible sense. This suggestion does not, however, answer every question concerning the forms, locations, content, structures and methods of such programmes. There is certainly no sense that all the argument does is to provide a post hoc rationalization of existing practice. Researchers need to ask questions such as what scope there is for programmes that instruct people in selections of generic skills that cross the existing subject divisions. They need to look at the practical settings in which people live, work, study and enjoy leisure so as to be able to identify previously unidentified scope for Information Literacy activities. The development of Information Literacy programmes can then draw on such research. If the programmes are developed in the spirit of action research, they can then feed back into a broader expansion of knowledge on the empowerment of people through their command of access to and use of information. There is enormous, unexploited scope for professional activity in the area of Information Literacy and a clear map for such activity can be derived by a line of reasoning that begins with the idea of an information right.

\section{REFERENCES}

ALA. 1989. Presidential Committee on Information Literacy. Final Report. Chicago: American Library Association.

Alexandria Proclamation. 2005.

URL: http://archive.ifla.org/III/wsis/BeaconInfSoc.html [accessed 4 July 2010]

ALIA. 2001. Statement on Information Literacy for all Australians.

URL: http://www.alia.org.au/policies/information.literacy.html [accessed 15

September 2009]

Andretta, S. 2007. Change and challenge: Information literacy for the 21st century. Adelaide: Auslib Press.

Bothma, T., E. Cosijn, I. Fourie, and C. Penzhorn. 2006. Navigating Information Literacy: Your Information Society Survival Toolkit. Cape Town, South Africa: Pearson Education South Africa.

Buttedahl, P., and D. Nkurunziza. 2005. An assessment of civic literacy in Uganda's local government. Kampala: Peace and Conflict studies, Makerere University.

Clark, P. 2001. British clubs and societies, 1580-1800. Oxford: University Press.

Curzon, SC., and LD. Lampert. 2007. Proven strategies for building an information literacy program. New York: Neal-Schuman Publishers Inc. 
Eisenberg, MB., CA. Lowe, and KL. Spitzer. 2004. Information literacy: essential skills for the information age. $2 \mathrm{~d}$ ed. Westport, CT: Libraries Unlimited.

Habermas, J. 1989. The Structural Transformation of the Public Sphere. Trans. T. Burger. Cambridge: Polity Press.

Horton Jr, FW. 2008. Understanding Information Literacy: A Primer. UNESCO. URL: http://unesdoc.unesco.org/images/0015/001570/157020e.pdf [accessed 21 January 2009]

IFLA. 2008. IFLA Manifesto on Transparency, Good Governance and Freedom from Corruption. URL : http://www.ifla.org/en/publications/ifla-manifesto-ontransparency-goodgovernance-and-freedom-from-corruption [accessed 15 June 2009]

Lau, J. 2008. Information Literacy: International Perspectives. IFLA Publications 131. München: K.G. Saur Verlag.

Lankshear, C., and M. Knobel. 2008. Digital literacies: concepts, policies and practices. New York: Peter Lang Publishing Inc.

Milner, H. 2002. Civic literacy: how informed citizens make democracy work. Hanover: University Press of New England.

New Zealand Digital Literacy Definition.

URL : http://www.digitalstrategy.govt.nz/Resources/Glossary-of-Key-Terms/ [accessed 27 September 2009]

Norway. 2005. There shall be freedom of expression: proposed new Article 100 of the Norwegian Constitution. Official Norwegian Reports NOU 1999: 27, 39. Oslo:

Ministry of Justice and the Police.

Ofcom. 2009. Report of the Digital Britain Media Literacy Working Group. URL: http://www.ofcom.org.uk/advice/media_literacy/media_lit_digital_britain/digitalbritai n.pdf [accessed 27 September 2009]

Prague Declaration. 2003. Towards an information literate society. URL : http://portal.unesco.org/ci/en/files/19636/11228863531PragueDeclaration.pdf/Prague Declaration.pdf [accessed 21 January 2009]

Scottish Information Literacy Project. 2004-2009.

URL: http://www.caledonian.ac.uk/ils [accessed 17 September 2009]

Shor, I. 1980. Critical Teaching and Everyday Life. Chicago: University of Chicago Press.

Spencer, J., and C. Millson-Martula. 2009. Critical thinking within the library program. London : Routledge.

The Universal Declaration of Human Rights. 1948. 
URL: http://www.un.org/en/documents/udhr/ [accessed 17 June 2009]

Thomas, N. 2004. Information literacy and information skills instruction: applying research to practice in the school library media center. Westport, CT: Libraries Unlimited.

UK Information Literacy Website.

URL : http://www.informationliteracy.org.uk/information_literacy.aspx [accessed June 16, 2009]

WSIS. 2003. Shaping Information Societies for Human Needs. Civil Society Declaration to the World Summit on the Information Society.

URL: http://www.itu.int/wsis/docs/geneva/civil-society-declaration.pdf [accessed 21 January 2009] 